\title{
Revised Nomenclature of Kitasatosporia setalba
}

\author{
S. ŌMURA,* Y. TAKAHASHI, Y. IWAI, AND H. TANAKA
}

The Kitasato Institute and School of Pharmaceutical Sciences, Kitasato University, Minato-ku, Tokyo 108, Japan

The specific epithet for Kitasatosporia setalba $(1,3)$ was in violation of Rule $12 \mathrm{a}$ of the International Code of Nomenclature of Bacteria (2). Therefore, the name of this organism is revised to Kitasatosporia setae (se' tae. M.L. gen. n. setae of Seta); the specific epithet refers to the source of original isolation, Tokyo, Japan.

\section{LITERATURE CITED}

1. International Journal of Systematic Bacteriology. 1983. Validation list 11. Int. J. Syst. Bacteriol. 33:672-674.

2. Lapage, S. P., P. H. A. Sneath, E. F. Lessel, V. B. D. Skerman, H. P. R. Seeliger, and W. A. Clark (ed.). 1975. International code of nomenclature of bacteria. 1975 Revision. American Society for Microbiology, Washington, D.C.

3. Ōmura, S., Y. Takahashi, Y. Iwai, and H. Tanaka. 1982. Kitasatosporia, a new genus of the order Actinomycetales. J. Antibiot. 35:1013-1019.

\footnotetext{
* Corresponding author.
} 